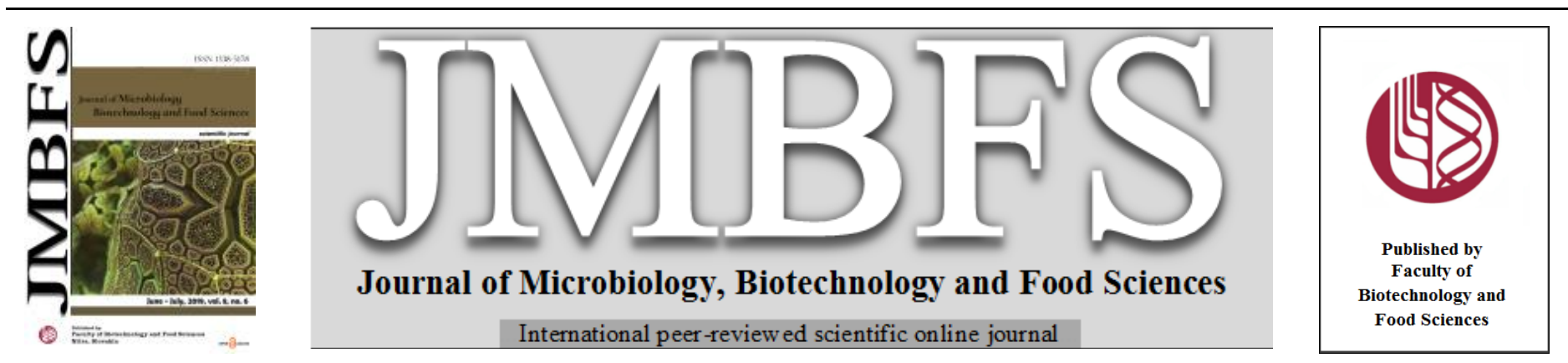

\title{
OXIDATIVE STABILITY OF CHICKEN MEAT AFTER USE OF OREGANO ESSENTIAL OIL
}

\author{
Michaela Klimentová ${ }^{1}$, Maria Angelovičovál , Jana Tkáčová2
}

Address(es): Michaela Klimentová.

${ }^{1}$ Slovak University of Agriculture, Faculty of Biotechnology and Food Sciences, Department of Food Hygiene and Safety, 949 76, Nitra, Tr. A. Hlinku 2, Slovakia, +421376415805.

${ }^{2}$ Slovak University of Agriculture, Faculty of Biotechnology and Food Sciences, Department of Evaluation and Processing of Animal Products, 949 76, Nitra, Tr. A.

Hlinku 2, Slovakia, +421376414348.

*Corresponding author: supermys0@gmail.com

doi: 10.15414/jmbfs.2019.8.6.1332-1334

\section{ARTICLE INFO}

Received 1. 10. 2018

Revised 28. 11. 2018

Accepted 14. 2. 2019

Published 1. 6. 2019

Regular article

OPEN $\partial_{\text {ACCESS }}$

\begin{abstract}
The purpose of this study was to investigate the effect of oregano essential oil on the oxidation stability of chicken meat. Oregano essential oil was applied in a different way, on the one hand in a feed for broiler chickens and on the other hand on a surface of chicken thighs.

The oxidative stability of the chicken meat was investigated in the same way, i.e. 30 minutes after vacuum-packed at room temperature and 6 months after vacuum-packed and storage at $-18{ }^{\circ} \mathrm{C}$. The samples of the $1^{\text {st }}$ experiment consisted breast and thigh muscles and skin and of the $2^{\text {nd }}$ experiment thigh muscle and skin. Broiler chickens were fed during the experimental period in the control group with commercial feed mixtures and in the experimental group with similar diets as in the control group but with the addition of $0.05 \%$ oregano essential oil. Application of oregano essential oil on surface of thighs was realized $1 \mathrm{ml}$ per $60 \mathrm{~g}$ of meat. The impact of oregano essential oil was measured by acid value. Number of acid value 30 minutes after oregano essential oil application in control group was significant higher $\left(6.69 \mathrm{~g} \mathrm{KOH} \mathrm{g}^{-1}\right)$ than in experimental group $\left(5.39 \mathrm{~g} \mathrm{KOH} \mathrm{g}^{-1}\right)$. Results of our experiments indicate that the oregano essential oil statistically significant $(\mathrm{p}<0.05)$ manifested an impact on the oxidative stability of chicken meat 30 minutes its action. The results impact of oregano essential oil on chicken meat stored at $-18{ }^{\circ} \mathrm{C}$ for 6 months were comparable to control group, but a tendency to improve oxidative stability was indicated. Feed addition of oregano essential oil did not show any effects on oxidative stability chicken meat.
\end{abstract}

\section{INTRODUCTION}

Consumers do not prefer synthetic antioxidants because of their carcinogenicity Moreover they preference natural food additives encouraged the foodstuffs industry to look for natural alternatives (Roohinejad et al., 2017). In this context, plant extracts have a important role in the food industry caused to their antioxidant and antibacterial effects since they are also ,generally recognized as safe“" (GRAS) (Vinceković et al., 2017). Lu et al. (2016) mention, that several compounds with antioxidant activity have been identified in plant extracts, in which phenolic compounds are considered as the major active group. Main cause for reduce food products quality, that is manifested by the appearance of offflavors, increased health risk (due to accumulation of toxic compounds) and decreased nutrient value, is oxidation reaction that often occur during processing and storage (Lorenzo et al., 2014). Free radicals cause oxidative deterioration of biomolecules such as membrane lipids, nucleic acids and proteins and antioxidants are defined as molecules that can prevent or delay oxidation of an oxidizable substrate, in this line (Halliwel and Whitemann, 2004). The mechanisms of oxidative degradation can be autoxidation in presence of atmospheric oxygen (Angelovič et al., 2015). Oxygen is a major component affecting lipid oxidation in meat as it reacts with unsaturated lipids to form lipid peroxides in a process of oxygen uptake and double bonds rearrangement. The formed lipid peroxides lead to the formation of various chemical compounds such as alcohols, aldehydes and ketones (Min and Ahn, 2012; Domínguez et al., 2014). Antioxidants react with radical and non-radical species to initiate defense mechanisms, after oxidative stress, for the protection of both intracellular and extracellular components. The plants are the richest source of antioxidants, which are largely present in spices, herbs, and essential oils. Plant-derived antioxidants provide meat processors with the flexibility to develop novel products with enhanced nutritional value and health benefits, an improved shelf-life, and an attractive quality profile (Jiang and Xiong, 2016). They are added in animal diets as nutritional supplements commonly to improve animal performance, health and welfare. Because, natural antioxidants added to meat animals feed, not only can improve the oxidative stability and organoleptic properties of meat but they also can enhance the nutritional value and the health benefit of meat products (Kasapidou et al., 2012). Antioxidant activity is attributed to several phenolic compounds, which are structurally related but differ in quantity and type, depending on the specific source. The major phenolic compounds in spices and herbs are phenolic acids (i.e., gallic acid, caffeic acid, and rosmarinic acid), phenolic diterpenes (i.e., carnosic acid and carnosol), flavonoids (i.e., catechin, quercetin, apigenin, kaempferol, naringenin, and hesperetin), and volatile oils (i.e., eugenol, carvacrol, thymol, menthol) (Brewer, 2011). Several authors have reported the effect and the antioxidant potential of oregano, which is among the most active natural extracts, mainly due to the action of phenolic-type compounds present in Origanum vulgare L., which is generally the species most studied (Spiridon et al., 2011). Fernandes et al. (2016) demonstrated that oregano extract indicate a high antioxidant activity when compared to other herbs, and can replace synthetic antioxidant without violation the sensory acceptability.

The presented literature demonstrated the potential for using of oregano and his extracts, as antioxidants in animal feeding and meat processing. The inhibitory effect of oregano essential oil on meat oxidation is mainly attributed to the numerous phenolic compounds with recognized antioxidant activity in vitro and in vivo. In conclusion, the use of oregano and his extracts is of great interest and potential usefulness for food companies as these extracts may replace synthetic antioxidants and preservatives and may actually present potential functional properties for consumers. However, unambiguous opinion on the mechanism of action of oregano essential oil or a uniform procedure for its application does not exist in literary sources.

The purpose of this study was to investigate the effect of oregano essential oil on the oxidation stability of chicken meat. Oregano essential oil was applied in a different way, on the one hand in a feed for broiler chickens and on the other hand on a surface of chicken thighs. 


\section{MATERIAL AND METHODS}

\section{Characterization of experiments}

Two experiments were carried out. The difference between the $1^{\text {st }}$ and $2^{\text {nd }}$ experiment was in the way of application of oregano essential oil. The application of oregano essential oil was performed in the $1^{\text {st }}$ experiment in the feed and in the $2^{\text {nd }}$ experiment on the surface of the chicken thighs. The oxidative stability of the chicken meat was investigated in the same way in both experiments, i.e. 30 minutes after vacuum-packed at room temperature and 6 months after vacuum-packed and storage at $-18{ }^{\circ} \mathrm{C}$.

The $1^{\text {st }}$ experiment was conducted in poultry farm, in conditions of the welfare principles application whit deep litter breeding system. The conditions responded protection requirements for broilers chickens Council Directive 2007/43/EC Microclimatic conditions (light, temperature, humidity and air exchange) were uniform for both groups in accordance with recommendations for the meat broiler chickens ROSS 308. Broiler chickens (40 one-day-old broiler chickens) were divided in the $1^{\text {st }}$ experiment into 2 groups, control and experimental $(\mathrm{n}=$ 20). Broiler chickens were fed during the experimental period in the control group with commercial feed mixtures without oregano essential oil and in the experimental group with similar diets as in the control group but with the addition of $0.05 \%$ oregano essential oil. Broiler chickens consumed of feed mixtures ad libitum. The experimental period lasted 38 day and tree feed mixtures were used: starter feed mixture, for chickens to 18 days of age (feed from plate feeders and water from the hat drinkers located on the floor); grower mixture, from 19 to 31 day of age (feed from the tube feeders and drank water from bucket drinkers till end of the experiment) and finisher mixture, from 32 to 38 day of age. Broiler chickens were transported to the chemical laboratory of Department of Food Hygiene and Safety, Faculty of Biotechnology and Food Sciences, Slovak University of Agriculture Nitra and killed after ending experiment. The breast and thigh muscles with skin were deboned and used for analyses (immediately after slaughter of broiler chickens and after 6 months of storage at $-18^{\circ} \mathrm{C}$ )

In the $2^{\text {nd }}$ experiment were broilers chickens killed on slaughterhouse and selected thighs randomly, after slaughtering. Chicken thighs were obtained from broiler chickens that were farmed and fed with commercial feed mixtures. Chicken thighs 24 pcs were deboned and used for analyses in the $1^{\text {st }}$ day (measurement 30 minutes after application of oregano essential oil on the surface of thighs) (12 pcs) and after 6 months (12 pcs). In both measurements were thighs divided to two groups: control group (6 samples without treatment), experimental group (6 samples with application of oregano essential oil on surface of thigh) The $1^{\text {st }}$ day 6 pcs of control group (after 30 minutes without oregano essential oil treatment) and 6 pcs of experimental group (30 minutes after action of oregano essential oil) were analyzed. Next 12 thighs; 6 pcs of control group (after 30 min without oregano essential oil treatment) and 6 pcs of experimental group (after 30 min with oregano essential oil treatment) were vacuum-packed and stored at -18 ${ }^{\circ} \mathrm{C}$ and were used for oxidative stability measurements after 6 months of storage time. Scheme of experiment is given in Table 1.

Table 1 Experiment scheme

\begin{tabular}{|c|c|c|c|}
\hline Experiment & $\begin{array}{l}\text { Broilers chickens Ross } 308 \\
\text { n }\end{array}$ & Sample preparation & $\begin{array}{l}\text { Oxidative stability } \\
\text { (chemical analysis) }\end{array}$ \\
\hline \multicolumn{4}{|c|}{ 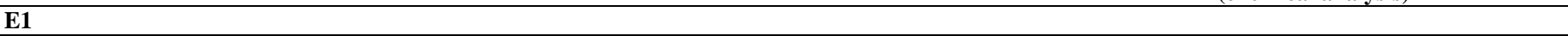 } \\
\hline Control group & 20 & $\begin{array}{l}30 \text { minutes after vacuum at room } \\
\text { temperature }\end{array}$ & $\begin{array}{c}\text { of chicken meat achieved from broiler chickens fed } \\
\text { with commercial feed mixtures without oregano } \\
\text { essential oil }\end{array}$ \\
\hline Experimental group & 20 & $\begin{array}{l}6 \text { months after vacuum- } \\
\text { packed packed and storage at }-18{ }^{\circ} \mathrm{C}\end{array}$ & $\begin{array}{l}\text { of chicken meat achieved from broiler chickens fed } \\
\text { with oregano essential oil } 0.05 \% \text { in the feed mixtures }\end{array}$ \\
\hline \multicolumn{4}{|r|}{ (2) } \\
\hline Control group & 6 & $\begin{array}{l}30 \text { minutes after vacuum at room } \\
\text { temperature }\end{array}$ & $\begin{array}{l}\text { chicken thighs without application of oregano } \\
\text { essential oil }\end{array}$ \\
\hline Experimental group & 6 & $\begin{array}{l}6 \text { months after vacuum- } \\
\text { packed packed and storage at }-18{ }^{\circ} \mathrm{C}\end{array}$ & $\begin{array}{l}\text { chicken thighs with application of oregano essential } \\
\text { oil } 0.5 \%\end{array}$ \\
\hline
\end{tabular}

E1- application oregano essential oil in the feed mixtures (50 g oregano essential oil per $100 \mathrm{~kg}$ feed mixtures), E2 - application oregano essential oil on the surface of chicken thighs $(1 \mathrm{ml}$ oregano essential oil per $60 \mathrm{~g}$ of meat)

\section{Sample preparation}

The samples consisted of: the $1^{\text {st }}$ experiment: breast and thigh muscles and skin the $2^{\text {nd }}$ experiment: thigh muscle and skin. In the $1^{\text {st }}$ experiment was half of samples ( $20 \mathrm{pcs})$ for chemical analysis prepared and 20 samples vacuum-packed and stored at $-18{ }^{\circ} \mathrm{C}$ for further analysis after 6 months of storage. In the $2^{\text {nd }}$ experiment were 6 samples (from $12 \mathrm{pcs}$ ) with oregano essential oil treated $(1 \mathrm{ml}$ of oregano essential oil applied on surface of thigh muscle $60 \mathrm{~g}$ ) and the same procedure was for further analysis (after 6 months of storage) repeated. Time of oregano essential oil treat was 30 minutes, amount $1 \mathrm{ml}$ per $60 \mathrm{~g}$ of meat. Chemical analysis (acid number) of the meat samples were carried out after homogenization (according to the method AOAC 983.18), drying of the samples under the prescribed conditions at $105^{\circ} \mathrm{C}$ to constant weight. The dried samples were then milled into powder using Grindomix GM 200 grinder and used to obtain fat by extraction (non-polar solvent) in a Soxhlet extractor.

\section{Chemical analysis}

Fat: was used an official method to determine fat AOAC 991.36. Crude fat content is determined by extracting the fat from sample using a chemical solvent (petroleum) under the extraction method. Lipid extraction was carried out using a device Det-gras N, model 4002842.

Acid value: Acid value test measures free fatty acids as an indication of hydrolytic rancidity. Free acids in a fat (or fat extracted from a sample) can be determined by titration. Acid value was determined according to AOCS (1997).

Acid number: a number expressing the acidity of a substance, equal to the number of milligrams of potassium hydroxide needed to neutralize the free fatty acids present in one gram of the substance (fat, oil, resin, etc). It is determined after diluted in a mixture of ethanol and diethyl ether by alkalimetric titration on phenolphthalein.

\section{Statistical analyses}

Results were statistically processed according to basic statistical characteristics ANOVA by the program SAS, version 9.1. The differences between groups were tested by Scheffe's test $(\mathrm{p}=0.05)$.

\section{RESULTS AND DISCUSSION}

Oxidative stability of chicken meat after application of oregano essential oil in the feed depending on the storage time

The oxidative stability parameter of the acid value after the application of oregano essential oil to the feed, measured in raw chicken muscle homogenates depending on its storage, is reported in Table 2.

Marcinčák et al. (2008), Hashempipour et al. (2013) indicate the positive antioxidant effect of Oregano vulgare L. for broiler chickens. On the other hand, Young et al. (2003), Roofchaee et al. (2011) this effect has not been confirmed in their work and claims that Oregano vulgare $\mathrm{L}$. do not show any antioxidant activity in chicken meat.

Table 2 The oxidative stability parameter of the acid value after the application of oregano essential oil to the feed, measured in raw chicken muscle homogenates depending on its storage time, $\left(\mathrm{mg} \mathrm{KOH} . \mathrm{g}^{-1}\right)$

30 minutes after action of oregano essential oil of vacuum-packed chicken meat at room temperature

\begin{tabular}{lcccc}
\hline Group & $\mathrm{n}$ & mean $\pm \mathrm{SD}$ & $\min$ & $\max$ \\
\hline Control & 20 & $4.35 \pm 1.14$ & 2.32 & 7.24 \\
\hline Experimental & 20 & $4.34 \pm 0.89$ & 2.63 & 5.84 \\
\hline $\begin{array}{l}\text { 6 months after action of oregano essential oil vacuum-packed of chicken } \\
\text { meat and storage at } \mathbf{- 1 8}{ }^{\circ} \mathbf{C}\end{array}$ & & & & \\
\hline Control & 20 & $9.17 \pm 2.79$ & 3.74 & 14.84 \\
& 20 & & 5.13 & 14.30 \\
\hline Experimental & & $9.57 \pm 2.07$ & & \\
\hline
\end{tabular}

Legend: control group - without oregano essential oil, experimental group - applied oregano essential oil in feed, $\mathrm{n}$ - number of samples, mean - arithmetical average, SD standard deviation, min - minimum value, max - maximum value

Number of acid value in control group was mean $4.35 \mathrm{~g} \mathrm{KOH} \mathrm{g}^{-1}$ and in experimental group mean $4.34 \mathrm{~g} \mathrm{KOH} \mathrm{g}^{-1}$ ( $\left.\mathrm{p}>0.05\right)$, and after 6 months was in control group mean $9.17 \mathrm{~g} \mathrm{KOH} \mathrm{g}^{-1}$ and in experimental group mean $9.57 \mathrm{~g}$ $\mathrm{KOH} \mathrm{g}^{-1}(\mathrm{p}>0.05)$. We found out in our experiment that the interaction between 
control and experimental group of oregano essential oil feeding broiler chickens was not significant in measurements of acid number of chicken meat. Impact of oregano essential oil did not show up to oxidative stability of the meat either after 30 minutes of treatment or after 6 months of storage compared to the control group. Measured acid values confirm that oregano essential oil has no effect on broiler chickens meat oxidative stability, if applied to feed.

Oxidative stability of chicken meat after application of oregano essential oil on surface of chicken thighs depending on the storage time

The oxidative stability parameter of the acid value after the application of oregano essential oil on surface of chicken thigh, measured in raw muscle homogenates depending on its storage, is reported in Table 3.

Natural antioxidants added to meat and feed for animals not only can improve the oxidative stability and organoleptic properties of meat but they also can enhance the nutritional value and the health benefit of meat products (Kasapidou et al., 2012).

Al-Hijazeen et al. (2016) recognized that oregano essential oil, at 0.03 and 0.04 $\%$ levels, showed the highest antioxidant effect to preserve the ground chicken meat. Shan at al. (2009) results showed that the natural extracts from oregano, applied to raw pork could help to reduce the final microbial load and inhibit lipid oxidation during storage at ambient temperature for up to 9 days. There contain high levels of bioactive phenolic compounds that can help to control food borne pathogens and inhibit lipid oxidation. Natural extracts may be more acceptable to consumers and also potentially benefit human health like as synthetic additives. Therefore such natural extracts might be used as multifunctional preservatives in meat.

Number of acid value 30 minutes after oregano essential oil application in control group was mean $6.69 \mathrm{~g} \mathrm{KOH} \mathrm{g}^{-1}$ and in experimental group mean $5.39 \mathrm{~g} \mathrm{KOH} \mathrm{g}$ ${ }^{1}$ ( $\left.\mathrm{p}<0.05\right)$, and after 6 months was in control group mean $9.30 \mathrm{~g} \mathrm{KOH} \mathrm{g}^{-1}$ and in experimental group mean $7.93 \mathrm{~g} \mathrm{KOH} \mathrm{g}^{-1}(\mathrm{p}>0.05)$.

The results of our research showed that a statistically significant difference in better oxidative stability compared to the control group was observed 30 minutes after application of oregano essential oil to the surface of chicken thighs ( $\mathrm{p}$ $<0.05)$. This tendency of improved oxidative stability has not been statistically confirmed in the measurement of chicken thighs samples stored for 6 months The results of chicken thigh samples stored at $-18{ }^{\circ} \mathrm{C}$ for 6 months were comparable, but a tendency to improve oxidative stability was indicated.

Table 3 The oxidative stability parameter of the acid value of fat after the application of oregano essential oil on surface of chicken thighs, measured in raw muscle homogenates depending on its storage time, $\left(\mathrm{mg} \mathrm{KOH. \textrm {g } ^ { - 1 } )}\right.$

30 minutes after action of oregano essential oil of vacuum-packed chicken thigs at room temperature

\begin{tabular}{lllll}
\hline Group & $\mathrm{n}$ & mean \pm SD & $\min$ & $\max$ \\
\hline Control & 6 & $6.69 \pm 0.88$ & 5.91 & 8.40 \\
\hline Experimental & 6 & $5.39 \pm 0.94$ & 4.08 & 6.63 \\
\hline
\end{tabular}

6 months after action of oregano essential oil vacuum-packed of chicken thigh and storage at $-18^{\circ} \mathrm{C}$

\begin{tabular}{lllll}
\hline Control & 6 & $9.30 \pm 2.80$ & 6.38 & 14.54 \\
\hline Experimental & 6 & $7.93 \pm 1.63$ & 6.31 & 10.60
\end{tabular}

Legend: control group - without oregano essential oil, experimental group - applied oregano essential oil in feed, $\mathrm{n}$ - number of samples, mean - arithmetical average, SD standard deviation, min - minimum value, max - maximum value

\section{CONCLUSION}

Results of our experiments indicate that the oregano essential oil manifested an impact on the oxidative stability of chicken meat in a moment after its application on surface of meat, i.e. 30 minutes its action. This effect was statistically significant compared with control group. The results impact of oregano essential oil on chicken meat stored at $-18{ }^{\circ} \mathrm{C}$ for 6 months were comparable to control group, but a tendency to improve oxidative stability was indicated. Feed addition of oregano essential oil did not show any effects on oxidative stability chicken meat.

Acknowledgement: Work was supported by KEGA 007SPU-4/2017.

\section{REFERENCES}

Al-Hijazeen, M., Lee, E. J., Mendonca, A., Ahn, D. U. 2016. Effect of Oregano Essential Oil (Origanum vulgare subsp. hirtum) on the Storage Stability and Quality Parameters of Ground Chicken Breast Meat. Antioxidants, 5(2), 18 https://doi.org/10.3390/antiox5020018

Angelovič, M., Jablonický, J., Tkáč, Z., Angelovič, M. 2015. Oxidative Stability of Fatty Acid Alkyl Esters: a review. Potravinarstvo Slovak Journal of Food Sciences , 9, (1), 417-426. https://doi.org/10.5219/500

AOAC (Association of Official Analytical Chemists), 1995 16th Ed., AOAC,

Washington, DC, USA.
AOCS, 1997. Official methods and recommended practices. 5th Ed. Commercial fats and oils. Washington, DC

Brewer, M. S. 2011. Natural antioxidants: Sources, compounds, mechanisms of action, and potential applications. Comprehensive reviews Food Science and Food Safety, 10, 221-247. https://doi.org/10.1111/j.1541-4337.2011.00156.x

Council directive 2007/43/EC of 28 June 2007 laying down minimum rules for protection of chickens kept for meat production. https://eur-lex.europa.eu/legalcontent/EN/TXT/?uri=CELEX:32007L0043

Domínguez, R., Gómez, M., Fonseca, S., Lorenzo, J. M. 2014. Effect of different cooking methods on lipid oxidation and formation of volatile compounds in foal $\begin{array}{llll}\text { meat. } & \text { Meat } & \text { Science, } & \text { 223-230 }\end{array}$ https://doi.org/10.1016/j.meatsci.2014.01.023

Fernandes, R. P. P., Trindade, M. A., Tonin, F. G., Lima, C. G., Pugine, S. M. P., Munekata, P. E. S., de Melo, M. P. 2016. Evaluation of antioxidant capacity of 13 plant extracts by three different methods: Cluster analyses applied for selection of the natural extracts with higher antioxidant capacity to replace synthetic antioxidant in lamb burgers. Journal of Food Science and Technology, 53(1), 451-460. DOI: 10.1007/s13197-015-1994-x

Halliwell, B., Whitemann, M., 2004. Measuring Reactive species and oxidative damage in vivo and in cell culture: how should you do it and what do the results mean? British Journal of Pharmacology. 142 (2), 231-255. https://doi.org/10.1038/sj.bjp.0705776

Hashemipour, H., Kermanshahi, H., Golian, A., Veldkamp, T. 2013. Effect of thymol and carvacrol feed supplementation on performance, antioxidant enzyme activities, fatty acid composition, digestive enzyme activities, and immune response in broiler chickens. Poultry Science, 92(8), 2059-2069. https://doi.org/10.3382/ps.2012-02685

Jiang, J., Xiong, Y. L. 2016. Natural antioxidants as food and feed additives to promote health benefits and quality of meat products: A review. Meat Science, 120, 107-117. https://doi.org/10.1016/j.meatsci.2016.04.005

Kasapidou, E., Wood, J. D., Richardson, R. I., Sinclair, L. A., Wilkinson, R. G., Enser, M. 2012. Effect of vitamin E supplementation and diet on fatty acid composition and on meat colour and lipid oxidation of lamb leg steaks displayed in modified atmosphere packs. Meat Science, 90(4), 908-916 https://doi.org/10.1016/j.meatsci.2011.11.031

Lorenzo, J. M., Pateiro, M., Fontán, M. C. G., Carballo, J. 2014. Effect of fat content on physical, microbial, lipid and protein changes during chill storage of foal liver pâté. Food Chemistry, 155, 57-63. https://doi.org/10.1016/j.foodchem.2014.01.038

Lu, W., Kelly, A. L., Miao, S. 2016. Emulsion-based encapsulation and delivery systems for polyphenols. Trends in Food Science \& Technology, 47, 1-9. https://doi.org/10.1016/j.tifs.2015.10.015

Marcincak, S., Cabadaj, R., Popelka, P., - Soltysova, L. 2008. Antioxidative effect of oregano supplemented to broilers on oxidative stability of poultry meat. Slovenian Veterinary Research, 45(2), 61-66.

Min, B., Ahn, D. U. 2012. Advances in Meat, poultry and seafood packaging, 112-153. https://doi.org/10.1533/9780857095718.1.112

Roofchaee, A., Irani, M., Mohammad, A. E., Mohammad, R. A. 2011. Effect of dietary oregano (Origanum vulgare L.) essential oil on growth performance, cecal microflora and serum antioxidant activity of broiler chickens. African Journal of Biotechnology, 10(32), 6177-6183.

Roohinejad, S., Nikmaram, N., Brahim, M., Koubaa, M., Khelfa, A., Greiner, R. 2017. Potential of novel technologies for aqueous extraction of plant bioactives Water Extraction of Bioactive Compounds, (1st Edition). 399-419. https://doi.org/10.1016/B978-0-12-809380-1.00016-4

Shan, B., Cai, Y. Z., Brooks, J. D., Corke H. 2009. Antibacterial and antioxidan effects of five spice and herb extracts as natural preservatives of raw pork Journal of the Science of Food and Agriculture, ; 89: 1879-1885. https://doi.org/10.1002/jsfa.3667

Spiridon, L., Bodirlau, R., Teaca, C. A. 2011. Total phenolic content and antioxidant activity of plants used in traditional Romanian herbal medicine Central European Journal of Biology, 6(3), 388 396. https://doi.org/10.2478/s11535-011-0028-6

Vinceković, M., Viskić, M., Jurić, S., Giacometti, J., Bursać Kovačević, D., Putnik, P., Režek Jambrak, A. 2017. Innovative technologies for encapsulation of Mediterranean plants extracts. Trends in Food Science \& Technology, 69, 1-12. https://doi.org/10.1016/j.tifs.2017.08.001

Young, J. F., Stagsted, J., Jensen, S. K., Karlsson, A. H., Henckel, P. 2003 Ascorbic acid, alpha-tocopherol, and oregano supplements reduce stress-induced deterioration of chicken meat quality. Poultry Science, 82(8), 1343-1351. 